\title{
Communication Privacy Management of Agricultural Extension Agent in Pandeglang Regency, Banten Province
}

\author{
Ari Surachmanto ${ }^{1}$; Prahastiwi Utari ${ }^{2}$; Andre Novi Rahmanto ${ }^{2}$ \\ ${ }^{1}$ Master of Communication Studies at Sebelas Maret University Surakarta, Indonesia \\ ${ }^{2}$ Lecturer in the Master of Communication Science Program at Sebelas Maret University Surakarta, \\ Indonesia
}

risurachwanto@gmail.com

\begin{abstract}
This research departs from a phenomenon that when the farmers in Pandeglang regency, Banten Province, are still carrying out farming activities outside of the recommended planting calendar issued by the Ministry of Agriculture Republic of Indonesia. The purpose of this study is to find answers to why farmers are not concerned about the planting calendar and how communication is carried out by agricultural extension workers with these farmers.

This study uses the theory of Communication Privacy Management (CPM). The approach used is descriptive qualitative. Data is collected by means of observation and in-depth interviews which are then presented descriptively. The results showed that farmers in Pandeglang district tended to use the traditional planting season, which was planting time from April to September. Farmers are not likely to get comprehensive information from extension officers because of technical issues such as limited seed varieties, fertilizers and medicines as idealized from the planting calendar. It was suggested that the Ministry of Agriculture should balance the idealism of farming as stated in the frog with the amount of agricultural logistics needed.
\end{abstract}

Keyword: Cropping Calendar; Communication Privacy Management; Agricultural Extension

\section{Introduction}

When the demand of rice production is supposed to increase for food security, on the other hand there is a contrast in supporting rice production with the decreasing land average farm ownership because today there is a lot of conversion of agricultural land. The fact that the conversion of agricultural land has changed a lot in the industrial and housing sectors which has caused the land ownership for businesses of farmers to be less than 0.25 hectares per household used for farming (BPTP Banten, 2016). 
In addition to the narrowing of arable land used by farmers to produce food crops, another obstacle that often arises threatens the rice production of farmers present to be affected by climate change whose anomalies have been quite high in recent years. Anomalies of this climate condition greatly affect the pattern and timing of planting, the potential for floods or droughts, affecting plant pest organisms (OPT) that can emerge, also determines the selection of plant varieties (Pramudia, Estiningtyas, Susanti, \& Suciantini, 2013).

As in El Niño who arrived in Indonesia in 2015, where Elino, which is a symptom of a deviation in the condition of rising sea surface temperatures, has caused a high temperature rise in the Earth's temperature resulting in a lack of rainfall and a long dry season. From this situation, many farmers in the field suffer a lot of losses due to drought and crop failure. However, reversing the situation in 2016, the farmers were faced with the arrival of heavy and prolonged rain, raising flood conditions in various places, and rediscovering many farmers who lost money due to the lack of anticipation.

To deal with these conditions, the Ministry of Agriculture (Kementan) of the Republic of Indonesia through the Indonesian Agency for Agricultural Research and Development (Balitbangtan) has developed an Information System for Planting Calendars which is an initial recommendation as an information tool for farmers to deal with climate in agricultural activities. At the beginning of the development process Balitbangtan has compiled a planting calendar atlas in 2007, then revised to be developed into a more dynamic Planting Calendar with information content for the beginning of planting time for extension workers and farmers.

Dissemination activities of the Planting Calendar conducted by extension agents to farmers are a form of persuasive communication activities. As expressed by Richard M. Perloff regarding persuasion which is a symbolic process in which a communicator tries to approach other people by giving confidence to others, in order to change from the attitude or behavior he has about an issue by sending messages in a free atmosphere to choose (Perloff, 2003). In the Planting Calendar socialization activities carried out by instructors, with persuasion communication there is a use of message symbols conveyed to farmers to change their attitudes and behavior which originally applied their agricultural activities in a conventional way, to be able to use the recommendations from the Planting Calendar to obtain the best productivity from commodities that planted it. In practice, the emotional closeness between extension agents and farmers personally is thought to have an impact on farmers' attention to planting calendar content. So that is close to the problem, extension agents need theoretical support for communication management in an intimate dimension with farmers.

\section{Research Methods}

This type of research is qualitative descriptive using case study design. The method and design are to find answers to why farmers do not care about the planting calendar and how communication is carried out by agricultural extension workers with these farmers. Qualitative research is intended to express the following picture of understanding how and why a phenomenon or reality of communication occurs (Pawito, 2007). 
Along with what Pawito said, Yin said in the case study there were " how " and " why 'questions that were directed to a series of contemporary events, where the researchers only had little chance or no chance to control the event (Yin, 2015). Patton (in Pawito, 2007) sees that a case study is an effort to collect and then organize and analyze data about certain cases regarding issues that concern researchers to then compare the data or connect with one another (in more than one case) by sticking to holistic and contextual principles.

Yin mentions that the source of evidence which is data for case studies can be summarized from documents, archive records, interviews, direct observations, observations and physical devices that can be used (Yin, 2015). Along with Yin's statement that the source of evidence for carrying out case study research can be taken from documents, archival records, interviews, direct observation, observation and physical devices, Pawito (2007) also emphasized that in qualitative research data can be obtained from interviews or interviews, observations, and data obtained from documents, narrated texts.

\section{Theoretical Framework}

Communication Privacy Management (CPM) is a theory that describes a map that shows that people make choices about disclosing or hiding private information based on criteria and conditions that they consider important, and individuals believe they have the right to own and regulate access to information. private (Petronio, 2002). Privacy Communication Management (CPM) is interested in explaining people's negotiation processes around the opening of private information. "CPM theory offers a privacy management system that identifies ways that privacy is coordinated between and among individuals" (Petronio, 2002). Communication Privacy Management (CPM) proposes five basic assumptions that support rule management systems. Based on this assumption, the CPM proposes a process of management rules for privacy regulation. These five basic assumptions define CPM properties. First, this theory concentrates on personal information. Second, boundary metaphors are used to describe the boundary between personal information and public relations. Third, control is a problem for two reasons. One, people believe that personal information is owned alone or shared with other people, thus, they want control over boundaries. Two, disclosing or hiding personal information can cause feelings of insecurity. Therefore, control is also important to be able to repel these feelings of insecurity. Fourth, this theory uses a rule-based management system to assist in making decisions about the ways boundaries are regulated. Fifth, the thought of privacy management is based on treating privacy and disclosure as dialectical or natural tensions (Petronio, 2002).

\section{Discussion}

The data obtained in the field shows how the extension workers in the field admit that for the sake of in-depth socialization of the planting calendar policy is impossible to the maximum. According to them, this is a problem that has two sides. The first side is the internal cause and the second is external. Internal causes actually come from the bureaucratic structure of the Ministry of Agriculture which does not prepare adequate and sufficient logistics. 
As one counselor said: 'We are indeed assigned to socialize the planting calendar, but there is a paradox that we will also find it difficult to bear the logical consequences of the socialization'. He said that the various consequences that arise could not be borne by the government, in this case the Ministry of Agriculture. For example, the issue of supplying certain varieties of rice seeds is recommended to be planted by farmers. Besides drugs and other agricultural needs are also limited, so it is absurd to give a suggestion but no consequences.

Furthermore, the second cause is external factors, in this case the cultivation culture adopted by the farming community in the Pandeglang district. An agricultural instructor can say that: " must be recognized that there is a clash of planting cultures in the context of this socialization. The calendar of planting based on knowledge and technology is trying to be applied in agricultural policy. While the farmer version of the planting calendar is based on conventional season calculations'. In this context, it is clear about the problem of culture, the customs of the local farming community are strong. Farmers feel comfortable with the basis of thinking about planting time, because it is very possible that it is a habit passed down from their parents. The sociological reality was acknowledged by a farmer who could say that: " we plant it traditionally ... our farmers standards on the planting season is from April to September ... every year ... that's enough ".

According to the benchmark farmers who have been hereditary it has been proven to survive until now as a technique of planting rice from the side of planting time. There is no explanation based on logical arguments about it, other than as a habit. Conventional season calculations in general such as the dry season from April to October seem to be the main reference. An agricultural instructor can say that: " in disseminating the planting period according to the calendar, we as extension agents only arrive at the level of providing information and appealing only. But it seems the farmers have their own reference in determining the planting period'. This is the reality that needs an established theoretical explanation. In the context of this study, extension agents are in a dilemma position, in relation to their duty to provide comprehensive information on policies according to the planting calendar. Then the instructor makes a kind of information valve to select information and to whom information will be provided. Of course with the hope that even though all information is given, the communicant will not protest with regard to the consequences that must be carried out. So there is a kind of boundaries that are deliberately created by the communicator in conveying the message of communication.

\section{Reasons for Opening and Closing Private Information}

There are several reasons that can encourage an individual, in this study an agricultural instructor, in opening up his private information. Individuals may hope to reduce the burden, gain control, enjoy selfexpression, or also may develop intimacy, but the goal is not always to gain intimacy (Petronio, 2002). Some reasons that encourage individuals to disclose their private information, namely to build trust in a relationship, to reduce the burden when the individual is experiencing stress and psychological disorders, and because of the enormous curiosity, demand, and insistence carried out continuously by other people. While some reasons that make an individual decide to close his private information, namely for fear of being rejected by those around him, the individual is afraid to disturb the psychological condition of others, and the individual does not want to damage his role as an exemplary figure the individual does not need to be open to the person. Individuals often hide information about others when the individual's needs are openly low (West \& Turner, 2010). 


\section{Control Private Information}

Individuals as the main owners of information want to be in control because there are risks about how this information is managed. In this study, informants also repeatedly exercised control over their private information. One way that individuals do to control private information is by asking the co-owner to keep their privacy confidential by not telling anyone about it. As the owner of information, individuals believe that they should be in a position to control who is allowed to gain access to information (West $\&$ Turner, 2010). Petronio (2002) also mentions that individuals who feel they are the main owners of information actively want to control what, when, and to whom the personal information is shared. The informant of this study also asked the head of the farmer group in Pandeglang who would hear his private information to keep the private information confidential. Another way to exercise control is to close the opportunity for access between the co-owner and other parties who are not permitted to access the private information they have.

\section{Rules in Managing Privacy}

Management systems provide a structure for understanding how personal information is handled (Petronio, 2002). For example, determine who receives disclosure, when, how much or how little, where the disclosure is, and how someone can hide that information. When individuals make decisions to open or close private information to others, individuals have certain criteria that influence the decision making. Decision criteria used by informants in this study to develop their privacy rules, among others, cultural criteria, motivational criteria (Self-defense need hypothesis, Self-need hypothesis, Self-knowledge need hypothesis), Life circumstances criteria, and criteria risk-profit ratio.

This boundary that marks the line of ownership is called privacy boundaries. Individuals make personal boundaries when their private information is not shared with others (West \& Turner, 2010; Petronio, 2002). In this study, the informant made personal boundaries for everyone regarding his private information regarding farmers who received complete information from his side. Whereas if an individual opens private information to others, the individual will automatically form a collective boundary. When a private information is shared, the boundaries around it are called the collective boundary, and that information belongs to the existing (collective private information) relationship (Petronio, 2002).

The informant in this study again made a collective boundary when conveying his private information to one of the farmer group leaders. Collective boundaries made with the head of the farmer group experience constraints, causing the informant's private information to spread to members of the farmer group. Petronio (2002) uses the term boundary turbulence to show disruption in the way the co-owner controls and regulates the flow of personal information to third parties. The disruption of the limitations seen in the results of this study is when one member of the farmer group who knows about holistic agricultural information informs the other members, without asking permission first. This disruption by Petronio is called Fuzzy Boundaries. Fuzzy Boundaries illustrates the constraints caused by individual information owners and co-owners never discussing what can be disclosed and what doesn't. 


\section{Dialectical Tension and Impact of Expressions}

When individuals are faced with the choice to open or close themselves to others, in that individual there will be an attractive force to reveal or keep the private information. Attractive force to express or keep storing private information is called dialectical tensions. From the findings of the data in this study, informants experienced dialectical tension when they would share all policy information in the planting calendar to others. When the informant intends to open his personal boundaries to the head of the farmer group he is developing, the informant feels worried if the secret information is leaked to someone else, don't let the other farmers not accept it. But on the other hand, the informant was relieved when he conveyed his private information to the head of the farmer group he had built, as a manifestation of carrying out his duties well. Dialectical tension focuses on the tension between the desire and the need to be private through concealment and public behavior through disclosure (Petronio, 2002).

A disclosure makes information become at the public level. The level of publicness depends on a number of issues, such as how many people know the information, how much information is disclosed, and who receives the information. When the informants in this study conducted private disclosure to the farming community with 100 peoples for example, the impact was public disappointment. So the informant chose not to reveal fully. When someone expresses personal feelings to the public it is often risky because it can caused embarrassment (feel embarrassed), feeling uncomfortable (feeling uncomfortable), and feeling somehow exposed (Petronio, 2002). It seems that communicators, in this context agricultural extension workers, are aware of this.

\section{Conclusion}

In this study conclusions can be drawn about how agricultural extension workers close and regulate the limits of their communication about planting calendars to farmers. The researcher found that individuals impose privacy restrictions on farmers by conveying only a portion of the policy on the planting calendar. The results of the study also show how individuals regulate the limits of their privacy communication to farmers who are emotionally closer to him. The results showed that farmers in Pandeglang district tended to use the traditional planting season, which was planting time from April to September. Farmers are not likely to get comprehensive information from extension officers because of technical issues such as limited seed varieties, fertilizers and medicines as idealized from the planting calendar. It was suggested that the Ministry of Agriculture should balance the idealism of farming as stated in the frog with the amount of agricultural logistics needed.

\section{Bibliography}

Balai Pengkajian Teknologi Pertanian Banten. (2016). Pendampingan Kalender Tanam dan Modis, Moderate Resolution Imaging Spectroradiometer. Serang: Badan Penelitian dan Pengembangan Banten, Kementerian Pertanian. 
Pawito. (2007). Penelitian Komunikasi Kualitatif. Yogyakarta. PT.LKiS Pelangi Aksara Yogyakarta.

Perloff, Richard M., (2003) Dynamic of persuasion. Communication and attitudes in the $21^{\text {st }}$ Century, New Jersey: Lawrence Erlbraum Associates.

Petronio, S. (2002). Boundaries of Privacy: Dialectics of Disclosure. USA: State University of New York.

Pramudia, A., Estiningtyas, Woro., et.al. 2013. Fenomena dan Perubahan Iklim Indonesia serta Pemanfaatan Informasi Iklim untuk Kalender Tanam. Kalender Tanam Terpadu. Bagian 2 bab 3. Kalender Tanam Terpadu. Kementerian Pertanian.

Yin, Robert, K., (2015). Studi Kasus: Desain dan Metode (M. Djauzi Dzakir). Jakarta. PT. Rajagrafindo Perkasa.

West, R \& Turner L.H. (2010). Introducing Communication Theory: Analysis and Application (4th ed). New York: McGraw Hill Higher Education.

\section{Copyrights}

Copyright for this article is retained by the author(s), with first publication rights granted to the journal.

This is an open-access article distributed under the terms and conditions of the Creative Commons Attribution license (http://creativecommons.org/licenses/by/4.0/). 